\title{
MARC Record Services: \\ A Comparative Study of Library Practices and Perceptions
}

\author{
By Rebecca Kemp ${ }^{1}$
}

\begin{abstract}
The number of journal titles available in digital format to libraries through aggregators and publisher packages has increased, but library resources to catalog these titles have not kept pace with the increases. More libraries are therefore turning to MARC record service vendors to provide batches of electronic serials bibliographic records, either full or brief. This study presents the results of a survey asking library personnel about their experiences with and attitudes toward MARC record services. While many survey participants expressed satisfaction with the services, they also responded that they would like a greater number of more accurate full bibliographic records. Also, while a majority of libraries use a separate records approach with the services, a significant minority use a single record approach.
\end{abstract}

KEYWORDS: MARC record services, MARCit!, Serials Solutions, single record approach, separate records approach, electronic serials cataloging, brief records

\section{NOTES}

1. This is a preprint of an article that was accepted for publication in The Serials Librarian (C) 2008 Taylor \& Francis. The article appears in The Serials Librarian v.55, no.3 (2008): 379-410 with different textual formatting. A URL for this article in Informaworld is not yet available, as of 12/09/2008.

2. Because this document was posted on the web before final review by the editor, certain corrections were made before publication in The Serials Librarian. These corrections can be found in Appendix II: Corrigenda, while the originally posted text follows.

\footnotetext{
${ }^{1}$ Rebecca Kemp, Serials Coordinator, Randall Library, University of North Carolina Wilmington. Mailing address: William Madison Randall Library, 601 S. College Rd., Wilmington, NC 28403. Preferred e-mail address: rlkemp@gmail.com. MSLS: University of North Carolina Chapel Hill, 2004; AB: Princeton University, 2002.

The author wishes to thank Jim Cole, of Iowa State University, Paul Moeller, of University of Colorado at Boulder, and Cecilia Genereux, of University of Minnesota Twin Cities, for their indispensable help in formatting the survey instrument used in this study. The author also wishes to thank Paul Moeller, Carmel Yurochko, of Duquesne University, John Reynolds and Nicole Pelsinsky, both of Serials Solutions, and Syed Ahmed and Kathryn Heavey, both of Ex Libris, for their aid in providing information regarding MARC record services.
} 


\section{MARC Record Services: \\ A Comparative Study of Library Practices and Perceptions}

\section{Introduction and Review of Relevant Literature}

The thousands of serial titles currently being made available electronically by publishers are the quintessential "moving targets." As serialists know well, journal titles often change; titles may cease, merge, or "divorce;" aggregators may lose permission to make certain titles available in an aggregator database.

To add to these problems, most libraries do not have sufficient personnel to catalog the proliferation of titles, let alone to track changes in these titles after their initial cataloging. Because of this, many libraries have chosen not to catalog all the titles available in aggregator databases. The author's own library has not, to date, included in its catalog all bibliographic records for the titles available through aggregator databases. Not including all titles poses a great challenge for the public catalog, if libraries want it to remain the primary search tool for patrons. As Maria Collins states, many librarians wish their library OPACs to be the "comprehensive access point for all their library holdings.",

How, then, do libraries solve the problem of too many titles, too little time and too few resources to include them all in the catalog? Robert Bland, Timothy Carstens, and Mark Stoffan refer to three major methods for providing access to electronically available titles: (1) creating alphabetical lists of titles with links and holdings information; (2) including links to the electronic version of a serial in the bibliographic record for the print version of the title; or (3) employing the "separate records" approach to cataloging, by using the bibliographic record specifically designed for the electronic version of a title in

\footnotetext{
2 Collins, Maria. "The Effects of E-journal Management Tools and Services on Serials Cataloging." Serials Review 31 (2005): 291-297.
} 
addition to the bibliographic record for the print version of the title. ${ }^{3}$ Neither the first nor the second approach requires bringing separate bibliographic records into the catalog for electronic versions of titles. In fact, the alphabetical list of electronic journals does not even require any information at all to be in the catalog. Separate lists can be maintained outside the catalog, such as the lists generated by EBSCO's A-to-Z service or the University of North Carolina at Greensboro's Journal Finder product. ${ }^{4}$ Nor does placing links for the electronic versions of titles into the print bibliographic records require a massive influx of new bibliographic records into a catalog. Bland, Carstens and Stoffan note that this approach reduces the number of duplicate hits for titles, thereby reducing patron confusion regarding the availability of titles. ${ }^{5}$

By way of contrast, the separate records approach requires the introduction of potentially thousands of new bibliographic records into the OPAC, and many of the titles to be brought into the catalog are electronic versions of titles that already have print records. The difficulties created by the existence of multiple records per title can also be compounded by the necessity of adding records for each different library that may share a consortial catalog.

Many libraries that use the separate records approach are able to do so because they use MARC record services to bring electronic serial records into their catalogs. With these services, vendors provide sets of electronic serial bibliographic records to subscribing libraries. The libraries then batch load these record sets into their OPACs.

\footnotetext{
${ }^{3}$ Bland, Robert N., Timothy Carstens, and Mark A. Stoffan. "Automation of Aggregator Title Access with MARC Processing.” Serials Review 28, no.2 (2002): 108-112.

${ }^{4}$ For more information about EBSCO A-to-Z, see EBSCO Information Services, EBSCO A-to-Z, http://www2.ebsco.com/en-us/ProductsServices/atoz/Pages/index.aspx (accessed October 7, 2007). For more information about Journal Finder, see University of North Carolina at Greensboro, Journal Finder, http://journalfinder.uncg.edu/demo/ (accessed October 7, 2007).

5 Bland, Carstens and Stoffan, "Automation," 109.
} 
Available MARC record services include Serials Solutions 360 MARC Updates, Ex Libris' MARCit! service, EBSCO A-to-Z with MARC Updates, TDNet's Holdings Manager with MARC records, and Innovative Interfaces' relatively new Content Access Service (CASE) MARC record service. ${ }^{6}$ A more in-depth look at particular features of the services will appear later in the article.

To return to the discussion of the single record versus separate records approach, a library's decision on which strategy to use can be affected greatly by its adoption of a MARC record service. Abigail Bordeaux indicated that libraries that have previously taken a single record approach may switch to the separate records approach as a result of receiving record sets from a MARC record service. ${ }^{7}$ In 2005, Maria Collins found that most of the librarians she interviewed desired a single record approach, although they were not always able to take that approach. Some librarians expressed the view that the “access gained by quick automation processes offsets the single record approach." 8

Bordeaux found in her survey of a broad range of librarians that the split in approaches was approximately half and half, with proponents of the single record approach advocating its ease of use for patrons, and proponents of the separate records approach touting the increased access to titles through the catalog. Some libraries combined elements of both approaches. (An example of this would be using the same

\footnotetext{
${ }^{6}$ For more information on Serials Solutions 360 MARC Updates, see Serials Solutions 360 MARC Updates, 2007, http://www.serialssolutions.com/ss_360_marc_updates.html (accessed January 27, 2008). For more information on Ex Libris' MARCit!, see Ex Libris Ltd., Ex Libris SFX: MARCit!, 2008, http://www.exlibrisgroup.com/category/SFXMARCit! (accessed 1/27/2008). For more information on EBSCO A-to-Z with MARC Updates, see EBSCO Information Services, EBSCO A-to-Z, 2008, http://www2.ebsco.com/en-us/ProductsServices/atoz/Pages/atozinfo.aspx (accessed 1/27/2008). For more information on TDNet's Holdings Manager with MARC records, see TDNet, Holdings Manager, http://nylink.org/reference/pdf/TDNETHldgsMgr.pdf (accessed 2/1/2008). For more information on Innovative CASE with MARC records, see Innovative Interfaces, Inc., Digital Collections, 2006, http://www.iii.com/mill/digital.shtml\#case (accessed 1/27/2008).

${ }^{7}$ Bordeaux, Abigail. "Single, separate, or something in between: Results of a survey on representing electronic serials in the catalog." Journal of Internet Cataloging, 7, no. 3/4 (2004/2005): 37-48.

${ }^{8}$ Collins, "Effects," 293.
} 
bibliographic record for print and microform versions while using separate records for different electronic versions.) Bordeaux also found that while some libraries were considering switching from the single record approach to separate records, no one was considering switching from separate to single. ${ }^{9}$

At the 2006 North American Serials Interest Group (NASIG) conference, Jennifer Edwards presented Massachusetts Institute of Technology (MIT) Libraries' decision to maintain a single record approach while using vendor-supplied batches of records. At the same presentation, Betsy Friesen discussed an alternative: the separate records approach used in conjunction with a MARC record service at the University of Minnesota Twin Cities (UMTC). ${ }^{10}$ When MIT's libraries investigated implementing the MARCit! MARC record service, library staff determined that they could maintain a single record approach even while using MARCit!, because they designed a computer program, or script, to match loaded records with already existing records in the catalog. UMTC libraries (also MARCit! customers), however, decided to switch to the separate records approach. In addition to increased catalog access, UMTC library staff noted that adopting the separate records approach would allow catalogers to focus on other projects, and it would allow for better statistical counts of electronic titles. ${ }^{11}$

\section{MARC Record Services Case Studies}

Having briefly looked at potential ramifications of using a MARC record service, we will now turn our attention to the process by which libraries implement these services.

\footnotetext{
${ }^{9}$ Bordeaux, "Single, separate," 43.

${ }^{10}$ Edwards, Jennifer and Betsy Friesen. "Climbing the mountain: choosing the best path for serials record management." The Serials Librarian 52, no.3/4 (2007): 335-339.

${ }^{11}$ Edwards and Friesen, "Climbing the mountain," 338.
} 
Rather than being a passive experience, subscribing to a MARC record service requires input and action by library customers.

Although there are more than two MARC record services available to libraries, for the sake of brevity, case studies will be presented only for two services: Serials Solutions 360 MARC Updates and Ex Libris MARCit! ${ }^{12}$ The reason for targeting these two services is that several implementation presentations are available on the web for each. In addition, the ALA session at the 2007 annual conference entitled "Doing Less to Do More: Incorporating Outsourced MARCs and Brief Bibs for Serials Discovery” produced two presentations on this topic that are available on request from the authors, respectively Paul Moeller and Cecilia Genereux. ${ }^{13}$ Both SFX and Serials Solutions also have user guides available for people interested in the MARC record services. The following case studies are meant to serve as a brief overview of the record profiling and loading process, rather than an in-depth study.

Case Study 1: Serials Solutions 360 MARC Updates at University of Colorado at Boulder

The University of Colorado at Boulder (UCB) serves as a case study of a library's use of Serials Solutions 360 MARC Updates. This description appears, in large part, courtesy of Paul Moeller, Serials Cataloger at UCB. ${ }^{14}$ UCB subscribes to Serials Solutions 360 Core (previously “Access and Management Service (AMS)”), which includes an A-Z journal list using a "knowledgebase" of titles and holdings. UCB also

\footnotetext{
${ }^{12}$ In addition, these two services were the most used by the survey respondents in this study.

${ }^{13}$ Available upon request: Moeller, Paul, 2007. Doing Less to do More: incorporating outsourced MARCs and brief bibs for Serials discovery, presented at the American Library Assocation Annual Conference, Washington, DC. Also available upon request: Genereux, Cecilia, 2007. Doing Less to Do More: University of Minnesota's use of MARCit! presented at the American Library Assocation Annual Conference, Washington, DC.

${ }^{14}$ This case study was written with information from the author's personal communications with Paul Moeller (University of Colorado Boulder), John Reynolds, and Nicole Pelsinsky (both of Serials Solutions). These three provided information in a series of e-mail exchanges and/or phone conversations between September 24, 2007 and January 29, 2008.
} 
subscribes to 360 MARC Updates to provide bibliographic records for the titles contained in the knowledgebase.

UCB began to set up the knowledgebase in 2004, using Serials Solutions AMS to indicate the titles for which UCB had online access. UCB library personnel have been making adjustments since that time, when titles or packages either become available or are no longer available. In 2006, UCB decided to purchase 360 MARC Updates. Before Serials Solutions sent any bibliographic records, UCB indicated its preferred types of bibliographic records and certain modifications to the records, as described below. Serials Solutions was then able to produce records for the library, whether those records were found in a database or created by Serials Solutions.

It is worth noting that both Serials Solutions and SFX use the Library of Congress Cataloging Distribution Service's MARC Distribution Service Serials package as a source of bibliographic records to send to libraries. The records included are only those created by CONSER libraries. When Serials Solutions is unable to find a CONSER online record, Serials Solutions uses a library "profile" that indicates, in order of preference, which kinds of records the library would like to receive. Choices include CONSER online records, CONSER print, microform, or CD-ROM records, and CONSER "neutral” records (which provide no indication of format). Further record options are National Library of Medicine records, Serials Solutions-created full records, and finally, Serials Solutions-created brief records. Brief records contain only a bare minimum of information. In setting up the library profile, UCB chose to receive the various types of CONSER records before those created by Serials Solutions. 
UCB also was given the option to customize their bibliographic records; for example, they specified that they would like a 130 uniform title field with the qualifier “(Online)" and the electronic resource general material designation in the 245 field.

Several other customization options exist.

After UCB set up their profile, they were ready to load a batch of records. Serials Solutions made the batch of records available for the library to download via FTP. UCB then brought the batch into their Innovative ILS by means of a piece of software known as the loader. During the load process, UCB changed 856 fields into 956 fields, so that the URLs from the bibliographic record would not display in the catalog. (UCB prefers to display holdings and URLs not within the bibliographic records, themselves, but in attached holdings records.)

Since the initial load of records, UCB has regularly received updated load files from Serials Solutions consisting of new records, existing records that have been changed, deleted records, and brief records. Each type of record comes in a different batch, which UCB is then able to load. Because brief records have no unique identifier, UCB deletes all brief records that were previously loaded before loading a new batch of brief records, to avoid introducing duplicate brief records into the catalog. Serials Solutions plans to add unique identifiers to brief records later in 2008 to alleviate this problem.

Case Study 2: Ex Libris MARCit! at Duquesne University

Duquesne University uses Ex Libris MARCit! The following description is available, in large part, courtesy of Carmel Yurochko, Serials/Electronic Resources 
Librarian. ${ }^{15}$ Yurochko and Bruno Mastroianni of Duquesne University also have a presentation detailing the Duquesne experience available online. ${ }^{16}$ The process for receiving MARCit! record batches is similar to that for Serials Solutions 360 MARC Updates. Initially, Duquesne library staff set up the SFX knowledgebase using a module within the SFX Admin center called the knowledgebase manager, or KBManager. The knowledgebase served to identify the library's electronic serials holdings and to inform MARCit! personnel of which bibliographic records to send. Unlike Serials Solutions, MARCit! sends only either CONSER base records or brief records; libraries are not given a choice to prioritize the kind of records they receive. However, if full CONSER records become available for brief record titles, MARCit! sends the CONSER records in the next load of records.

To initiate a request for a batch of records, in the SFX Admin Center, library staff selected "MARC Enhancement" and indicated that they wished a fresh export of the records for all available titles in the knowledgebase. They also were able to customize the records: they chose to display the electronic resource general material designation in the 245 field of the records as well as Duquesne-specific authentication information in the 856 fields. Library staff then received an e-mail notification that a batch of records was ready for loading. Attached to the e-mail was a statistical report that included the number of new, updated, and deleted records. (The number of updated and deleted records is always zero for fresh exports, as there is no comparison with previous loads.)

\footnotetext{
${ }^{15}$ This case study was written with information from the author's personal communications with Carmel Yurochko (Duquesne University), Syed Ahmed, and Kathryn Heavey (both of Ex Libris). These three provided information in a series of e-mail exchanges and/or phone conversations between October 10, 2007 and January 31, 2008.

${ }^{16}$ Yurochko, Carmel and Bruno J. Mastroianni, "From 0 to 6000 in minutes." http://www.bc.edu/bc_org/avp/ulib/naaug2004/smugpresentations/mastronianni.ppt (accessed January 28, 2008).
} 
Library staff transferred the batch of records onto a local computer via FTP. They then edited the records in batch using MarcEdit, open source MARC record editing software, adding the 099 field subfield a "ELECTRONIC JOURNAL" to all records. ${ }^{17}$ Once the record editing was complete, the records were ready to be batch loaded into Duquesne's ILS.

Rather than downloading only updated records with each subsequent monthly load, Duquesne staff have chosen to download all available records. (Alternatively, libraries can choose to download only files that compare the previous load with newly available, changed, or deleted records. If libraries make this choice, each record's leader indicates whether the record is new, changed, or deleted.) All records, including brief records, have a unique SFX identifying number, so that modified records overlay older versions. Since Duquesne has chosen to receive fresh loads each time, records that have been deleted since the last load are not included in the current load. Therefore, to find records that need to be deleted, Duquesne staff run a report to generate a list of records that were not updated in the current load. Then they individually remove the records that were not updated.

\section{Survey Methodology}

The current study was composed of a twenty-one question survey administered online at Surveymonkey.com. The text of the survey is found in the appendix to this article. Most of the survey questions emerged in response to Paul Moeller's and Cecilia Genereux's presentations given at the American Library Association annual conference, as mentioned above. Hearing about the respective load processes and necessary record

\footnotetext{
${ }^{17}$ For more information on MarcEdit, see Reese, Terry, MarcEdit: Your complete free MARC editing utility, http://oregonstate.edu/ reeset/marcedit/html/about.html (accessed January 27, 2008).
} 
modifications for each MARC record service prompted the author to wonder whether multiple libraries have chosen to load and modify the bibliographic records in similar ways. An issue of particular interest to the author was also whether libraries chose to use the single record or separate records approach, and whether this decision was affected by adoption of the MARC record service.

The survey had three basic goals: (1) to investigate whether any common practices have emerged in implementing and maintaining MARC record services, (2) to assess library personnel perceptions of the MARC record services, both positive and negative, and (3) to solicit feedback on desired improvements to MARC record services. $^{18}$

Survey participation was open to all the members of the listservs SERIALST-L, NASIG-L, ERIL-L, NGC4LIB, LIBLICENSE-L, and the Lis-e-journals Discussion List. Listserv postings announced the opening of the survey, and participants were given a week to respond to the survey.

\section{Results}

Because the survey sample was a self-selected group of participants, it is not possible to make generalizations about the practices or attitudes of all library personnel who use MARC record services. Presumably, however, other users of the MARC record services have similar practices, experiences, and concerns to the ones expressed in this survey.

Of 130 participants who began the survey (duplicate responses discounted), 26 participants completed the last substantive question, and varying numbers of participants

\footnotetext{
${ }^{18}$ Aggregate patterns are presented, rather than analysis of one service in comparison with another, in an effort to create a broader view of the services in general.
} 
answered the majority of the questions, which were not marked as required. In summarizing the results, the number of respondents for any specific question will be stated, so that readers may have a sense of the proportion of respondents who answered in a given way. ${ }^{19}$

The first two questions of the survey (see Tables 1 and 2) give a demographic profile of the respondents. Ninety out of 104 respondents $(86.5 \%)$ indicated that their library setting was academic. Ten $(9.6 \%)$ indicated that their library was a special library; three (2.9 percent) represented public libraries; and one (1\%) represented a library cooperative. Seventy-nine (76\%) of 104 respondents were located in the United States, nine $(8.7 \%)$ in the United Kingdom, six $(5.8 \%)$ in Australia, four $(3.8 \%)$ in Canada, two $(1.9 \%)$ in Lebanon, and one (1.0\%) each in Finland, New Zealand, North Africa, and Pakistan.

(TABLE 1)

(TABLE 2)

An attempt was made to establish the approximate number of electronic serial titles held by each participant's institution. The estimates ranged from under a thousand to over 200,000 . Six respondents $(5.8 \%$ of 104$)$ indicated that they did not know how many titles they held, but all other participants provided an estimate. Sixty-four participants (61.5\%) reported between one and 30,000 titles. The mean number of titles was approximately 29,346, while the median was 25,000 and the mode was 30,000. For the full range of responses, see Table 3.

\footnotetext{
${ }^{19}$ For multiple choice questions where the author was not initially sure what the full range of responses would be, respondents were able to choose "Other (please specify)," and they provided more possible responses. Where there were multiples of the same "other" response, summaries of any patterns are reported in the paper. Participants were able to choose more than one answer to several questions, meaning that any percentages calculated do not total to 100 .
} 
(TABLE 3)

One-hundred-and-four participants reported use of 13 different integrated library systems (ILSs). Thirty-four (32.7\%) reported using the Innovative Millennium ILS. Ex Libris Voyager came in second with 22 users (21.2\%), followed by Ex Libris Aleph with 15 users (14.4\%), SirsiDynix Unicorn with 13 users (12.5\%), SirsiDynix Horizon with eight users (7.7\%) and Talis Alto with five (4.8\%). The remaining seven ILSs were each represented by only one library. For all responses, see Table 4 .

(TABLE 4)

Most respondents, 92 out of 96 (95.8\%), reported that they provide access to serial titles and holdings information not only through the library catalog but also through an alphabetical list of titles. As seen in Table 5, the remaining four said that they provide access only through their catalog.

(TABLE 5)

When asked which MARC record service their libraries use, 96 respondents answered with eight different services. ${ }^{20}$ Sixty participants (62.5\%) selected Serials Solutions 360 MARC Updates, while 24 (25\%) chose Ex Libris MARCit! Together, Serials Solutions and MARCit! users constituted $87.5 \%$ of respondents. EBSCO MARC records garnered five responses (5.2\%), Cassidy Cataloging and TDNet both had two responses, and there was one response each for MARCIVE, TalisBase, and records provided by aggregators. No respondents reported using the CASE MARC record service. See Table 6 for the full breakdown.

(TABLE 6)

\footnotetext{
${ }^{20}$ One participant offered two different services, which would have brought the total number of answers to 97, but another participant submitted the answer "none," which was discounted.
} 
The next question asked whether respondents' libraries use a coverage service in addition to a MARC record service, such as Serials Solutions 360 Link, SFX, or CASE. The author initially understood "coverage service" to encompass both a knowledgebase and a link resolver. However, the author subsequently learned that it is possible to use a knowledgebase without using a link resolver. This was evident from the responses, because 17 respondents (17.7\% of 96 total) indicated that their libraries do not use a coverage service. Of those 17, 11 reported using Serials Solutions 360 as their MARC record service, one reported MARCit! as the library's MARC record service, and three reported using EBSCO MARC records. Two of the participants who use Serials Solutions MARC records added that their institutions use the Serials Solutions knowledgebase, but they have not implemented a link resolver. This is a likely situation for the other participants who indicated that their libraries do not use a coverage service. For a full breakdown of all coverage services reported, see Table 7.

(TABLE 7)

Since MARC record services can have such a great bearing on the decision of whether to use the single record or separate records approach, the next three questions addressed this issue. First, participants were asked whether they use a single record approach, separate records approach, or combine elements of the two approaches. Sixtyone of 96 respondents $(63.5 \%)$ indicated that they use a separate records approach. Twenty-two respondents (22.9\%) selected the single record approach, and 13 respondents (13.5\%) said that they combine elements of both approaches (see Table 8). The 
respondents who used both approaches were asked to provide an explanation of their

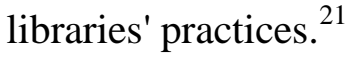

\section{(TABLE 8)}

Ten respondents described a variety of ways to implement a combined approach. Two participants recorded that they maintain separate records for different formats, except for Government Printing Office publications, for which they maintain single records. Two others noted that separate records are used except in the case of records that require original cataloging. One participant used a combined approach because the library is switching from a single record approach to separate records, while another participant reported that the library was switching to a single record, but not in a systematic manner. Another library used single records wherever ISSN-matching is possible through batch-loading, but separate records for titles that do not match on ISSN. The complexity of the choice between single and separate records is highlighted by all of the different possible scenarios and practices. For a full range, see Table 9.

\section{(TABLE 9)}

Of the 56 respondents who answered that their libraries use a separate records approach, $31(55.4 \%)$ said that their libraries transitioned from using a single record approach to separate records as a result of implementing a MARC record service. As shown in Table 10, the remaining 25 (44.6\%) did not transition to the separate records

\footnotetext{
${ }^{21}$ Investigation of these 17 explanations revealed that seven of these responses actually described a separate record approach. Initially, 56 respondents $(58.3 \%)$ indicated that they used a separate records approach and 18 (18.8\%) claimed a mixed approach. Taking into account respondents' comments about their combined approaches increased the number of participants taking a separate records approach and decreased the number of those taking a combined approach. Three respondents considered the use of one record for multiple instances of an online title to be a single record approach; one respondent indicated that a different bibliographic record is used for each different publisher platform for online titles.
} 
approach as a result of implementing the MARC service, which implies that their libraries had already adopted a separate records approach.

(TABLE 10)

Representing the single record approach, on the other hand, 20 of the 22 participants who indicated that they use a single record approach chose to answer the question, "Has the use of the single record approach created special problems for you in using the MARC record service?" Seven of those respondents (35\%) said that their use of the single record approach has created special problems, while the remaining $13(65 \%)$ did not. (See Table 11.)

(TABLE 11)

When asked to elaborate on the particular problems their libraries encountered, all seven offered further information, indicating eight different problems, in all. Five of the responses mentioned that the libraries have to deal with duplicate records: one institution had duplicates as a result of sharing their catalog with two other institutions. Three more of the five indicated that duplicates exist because of inexact matches on title or ISSN between the old bibliographic record in the catalog and the new one brought in by the batch load. Beyond the existence of duplicates, the other problem that garnered more than one response was that of the caution needed in deleting records, because some records may have print holdings on them, or they may have special instructions or restrictions to access associated with them. For a summary of all responses, see Table 12.

(TABLE 12)

The next survey question asked about brief records: "In a typical load, what percentage of the bibliographic records loaded would you estimate are brief bibliographic 
records?" For a full breakdown of responses, see Table $13 .^{22}$ Significantly, 19 (32.8\%) of 58 respondents indicated that the typical percentage is zero; six of the 19 said that they do not accept brief records during their loads. ${ }^{23}$ Sixteen participants (27.6\%) estimated that between $1 \%$ and $10 \%$ of the records they receive are brief records. Thirty-two respondents $(55.2 \%)$ estimated that the percentage was between $1 \%$ and $40 \%$. The mean percentage of brief records was 20.2. ${ }^{24}$ The median percentage was 15 , and the mode was zero, with the next most frequent answer being ten.

\section{(TABLE 13)}

When participants were asked to choose from a list of features that may be common in brief records, 58 respondents identified one or more of the possible features, including the number of participants who selected "other" (28). The most frequently chosen response with 30 responses (51.7\%) was that brief records lack 780/785 linking fields. Eighteen respondents (31\%) selected "No persistent unique bibliographic record identifier;" 15 (25.9\%) selected "Incorrect ISSN;" 15 (25.9\%) selected "Incorrect use of diacritics;" $11(19 \%)$ selected "Duplicate records in the same batch;" 10 (17.2\%) selected "Inconsistent use of acronyms;" and six (10.3\%) selected "General material designation displays incorrectly." Of the "other responses" (in other words, these responses were entered in by participants, rather than being in the multiple choice array), the ones that gathered more than one response were as follows: "Lack of detail in the records," with

\footnotetext{
${ }^{22}$ As a caveat to this question, one respondent explained that the percentage of brief records is not a meaningful number, because all brief records are reloaded every month, but all full records are not. This statement implies that the percentage of brief records fluctuates from load to load depending on the number of full records that are loaded. The author assumes that the percentage does not change drastically from month to month, however, so that the responses are, in fact, meaningful.

${ }^{23}$ Seventy-three respondents made some answer to the question. In the process of analyzing the responses, however, 15 of those responses were discounted either because they were not represented in percentage format or the respondent answered that s/he didn't know. That left a total of 58 responses.

${ }^{24}$ For the purpose of calculating the mean answer, five answers that did not give precise numerical values, e.g., "less than 2 percent", were discounted, leaving a total of 53 responses to the question.
} 
nine responses (15.5\%); "Library chooses not to use brief records," with seven responses (12.1\%); and "Incorrect title proper," with three responses (5.2\%). For all responses, see Table 14.

\section{(TABLE 14)}

In a question parallel to the previous question, participants were asked to choose from a list of features that are common in full records. Fifty respondents identified one or more of the possible features, including the number of participants (22) who selected "other." Almost half of the respondents (24, or 48\%) indicated that full records contain notes for print or microform versions. This was not necessarily perceived as a negative; three respondents $(6 \%)$ said that they were satisfied with the records as they were, even if they contained print or microform information, because the respondents either selected those records to be added to their profiles or were able to tell the MARC record service vendor to remove them, and the vendor would comply. Twelve respondents (24\%) chose "Fixed fields have incorrect values for online version;" nine (18\%) chose "ISSN for electronic format is in 776 field rather than 022 field;" six (12\%) chose "Records are missing 245 |h [electronic resource];" another six chose "Links in 856 fields are incorrect;" and four (8\%) chose "Coverage dates in 008 are incorrect for records with 785 fields." Of "other" responses entered in by participants, nine (18\%) said that they didn't know or haven't noticed any patterns of common features in the full records. Two respondents (4\%) stated that title changes are not documented correctly. For a list of all responses, see Table 15 .

(TABLE 15) 
In answer to the question, "After your library loads the bibliographic records, how do you modify them?" 71 respondents chose one or more of the provided answers, including "Other (please specify)". The highest number of respondents, 28 (39.4\%), indicated that they make no modifications to the bibliographic records. Twenty-five respondents $(35.2 \%)$ batch-update records using their integrated library systems, and an additional person responded that his/her library applies a particular material type code to the records, which is also an enhancement made with the ILS. Fifteen participants (21.1\%) reported fixing bibliographic records by hand post-load. Thirteen (18.3\%) reported that they batch-update their records using scripts. Eight $(11.3 \%)$ indicated that they modify their records before running the loads, rather than afterwards. Of these respondents, four reported using MarcEdit, as in the process used at Duquesne. Pre-load edits included removing MeSH headings, adding call numbers, removing unwanted fields and adding 099 fields. Four respondents (5.6\%) indicated that rather than modifying the records themselves post-load, they notify the vendor and ask for records to be corrected. For a full chart of responses, see Table 16.

(TABLE 16)

There was limited consensus among respondents when they were asked how they would enhance/improve the MARC records, either full or brief, if they could. Of 35 different respondents, eight $(22.9 \%)$ said that they would like fewer brief records to be present in the loads. ${ }^{25}$ Seven respondents (20\%) indicated that they were satisfied with the quality of the records. Six $(17.1 \%)$, however, said they would like the records to be more accurate. Five (12.5\%) said that they would like for a persistent unique identifier to

\footnotetext{
${ }^{25}$ Forty participants initially responded, but five responses were discounted, because they did not pertain directly to improvements in the records.
} 
be added to brief records. Three $(8.6 \%)$ said that they would like to be able to use OCLC member-created records for online titles rather than CONSER records, if no satisfactory CONSER record is available. Three (8.6\%) wanted subject headings to be modified, either so that there are fewer Library of Congress headings or English-only headings. For a summary of all responses, see Table 17.

\section{(TABLE 17)}

The next two questions asked for perceptions, both positive and negative, of the services. Seventy-one respondents chose one or more of the options (including "other") in answer to the question, "What do you like best about the MARC record service?" Fifty-three respondents (74.6\%) chose as a favorite the "Satisfaction of being able to spend time on projects other than cataloging aggregated titles." Fifty-one respondents (71.8\%) indicated that "Satisfaction of knowing that all titles have bibliographic records" was an outstanding feature. Forty-nine participants (69.0\%) appreciated "Ease of use in loading records." Fourteen respondents (19.7\%) chose "Accuracy of bibliographic records." Of the other responses volunteered by participants, seven greatly appreciated the fact that the MARC record services create access to titles that would not otherwise have access through the catalog. For all responses, see Table 18.

\section{(TABLE 18)}

For the sake of contrast, the next question asked participants what they like the least about the MARC record service. Fifty-eight respondents chose one or more answers (including "other"). Twenty-five (43.1\%) indicated that they least like the inaccuracy of the bibliographic records. Eighteen (31\%) chose the time spent cleaning up bibliographic records after the load as a significant drawback. Twelve (20.7\%) reported the difficulty 
of the load process as a least favored feature. Six respondents (10.3\%) indicated that they are satisfied with the service as it is. Four (6.9\%) wrote that they receive either too many brief records or duplicate brief records. Three (5.2\%) wrote that they have problems loading the records. Another three (5.2\%) responded that they either don't know or don't have time to check the bibliographic records in order to report on their features. Two (3.4\%) said that they do not receive records for all of the titles in their profiles. For all responses, see Table 19.

\section{(TABLE 19)}

The last question with a specific focus asked participants how they would enhance or improve the overall load process, if they could. ${ }^{26}$ Of 30 respondents, seven (23.3\%) said that it works well enough as it is. Four respondents (13.3\%) indicated that either they didn't know or had no comment. Three wanted better brief records (10\%), and another three wanted the load process to be easier or more automated. Two (6.7\%) indicated that their ILSs have trouble handling load; two want to load "cleaner," more accurate records; and two posited that it is not possible to improve the process. For a summary of all answers, see Table 20.

(TABLE 20)

Twenty-six participants answered the final question, "Do you have any further comments about the MARC Record Service?" Ten (38.5\%) provided positive feedback, either saying that they like the additional access afforded by the service or that they are satisfied with the service in general. Two (7.7\%) said that although using the service has created problems, it is a necessary addition to the catalog. Another two respondents said

\footnotetext{
${ }^{26}$ Thirty-two participants initially responded, but two responses were discounted, because they needed further clarification, and the author was unable to contact the participants.
} 
that the single record approach is difficult to achieve using the service. All of the rest of the responses were only entered by one person each, and most of the other responses have already been addressed by another question in the survey (see Table 21).

(TABLE 21)

\section{Discussion and Conclusion}

Certain trends are apparent from the data collected in the survey, although the open-ended nature of several of the questions allowed for many different responses. The respondents' libraries, themselves, bear some similarities to one another: most of the libraries represented $(86.5 \%)$ are academic libraries. They are likely to have access to between 25,000 and 30,000 electronic serial titles. The majority (95.8\%) are providing access to their electronic serials collections not only through the catalog, but also through an A-Z list. Having the catalog access is important enough to these libraries that they are willing to invest the resources in implementing a MARC record service, so this is a testament to its perceived value. The two services used by most respondents are Serials Solutions 360 MARC Updates and Ex Libris MARCit! EBSCO MARC records served as the next most popular service.

Regarding practices employed at different libraries, one of particular interest was the decision of whether to use a single record approach, separate records approach, or a combination. In this area, responses were fairly split. Although most libraries use a separate records approach, at $63.5 \%$, a far greater number of libraries maintained a single record approach than the author would have expected (22.9\%). Second, it appears that the adoption of a MARC record service was about as likely as not to convert a library to the separate records approach; only about half of the libraries who reported using the 
separate records approach said that they had been "converted" by adopting the MARC record service. Implementing a MARC record service did not seem to be as great a factor in the libraries' decisions as the author would have expected.

Of the libraries who maintain a single record approach, surprisingly, fewer respondents reported problems than those who reported none. The problems, however, were to be expected: that of the existence of duplicate records, and trying to avoid deleting necessary records that might have been flagged for deletion.

The second area of practices that libraries shared was that of modifying vendorprovided records. Since a number of respondents were satisfied with the records, they often chose not to modify the records (39.4\% of 71 respondents). Of those who do modify, however, the largest number use their ILSs to batch update the records, followed by those who fix records by hand, with running scripts on the records coming in third. Modifying records using MarcEdit was also a relatively popular choice.

Library staff also shared several perceptions of the records. Brief records appear most often to lack detail or accuracy, as evidenced by missing 780/785 linking fields, correct ISSNs, and incorrect diacritics; not to mention, in some cases, missing unique identifiers. (This should be rectified soon for Serials Solutions brief records.) Brief records also appear to comprise about $20 \%$ of the typical record load. Full records display format information for non-electronic materials, but respondents know that this is what they have requested from the service providers. To complement these trends, library personnel wish to modify the records by receiving fewer brief records and more accurate records. A large number of respondents are satisfied with the records as they are, however. 
The MARC record services have great advantages, as perceived by the respondents: library staff most appreciate being able to spend time on projects other than cataloging and knowing that all electronic serials have some access in the catalog, including titles that never otherwise would have been input into the catalog. To offset these distinct advantages, though, about $40 \%$ of respondents indicate that there is room for improvement in the accuracy of the records.

Overall, the library personnel surveyed held a generally positive view of the services, which create access that was not previously available. On the other hand, it seems inevitable that automating the process of creating catalog records, which have traditionally required a great deal of human judgment and oversight to produce, leads to inaccuracies in the records. Perhaps with time and technological advances, MARC record services will be able to adjust their processes and create records that meet, or exceed, the expectations of most library personnel. 


\section{TABLES}

TABLE 1. Library Setting

\begin{tabular}{lcc}
\hline Responses & Response Count & Response Percent \\
\hline Academic & 90 & 86.5 \\
Special & 10 & 9.6 \\
Public & 3 & 2.9 \\
Library Cooperative & 1 & 1.0 \\
Total & 104 & 100.0 \\
\hline
\end{tabular}

TABLE 2. Library Location

\begin{tabular}{lcc}
\hline Responses & Response Count & Response Percent \\
\hline United States & 79 & 76.0 \\
United Kingdom & 9 & 8.7 \\
Australia & 6 & 5.8 \\
Canada & 4 & 3.8 \\
Lebanon & 2 & 1.9 \\
Finland & 1 & 1.0 \\
New Zealand & 1 & 1.0 \\
North Africa & 1 & 1.0 \\
Pakistan & 1 & 1.0 \\
Total & 104 & 100.0 \\
\hline
\end{tabular}

TABLE 3. Approximate Number of Electronic Serials

\begin{tabular}{lcc}
\hline Responses & Response Count & Response Percent \\
\hline Unknown & 6 & 5.8 \\
$0-1000$ & 4 & 3.8 \\
$1001-10,000$ & 16 & 15.4 \\
$10,001-15,000$ & 13 & 12.5 \\
$15,001-20,000$ & 10 & 9.6 \\
$20,001-25,000$ & 8 & 7.7 \\
$25,001-30,000$ & 13 & 12.5 \\
$30,001-35,000$ & 8 & 7.7 \\
$35,001-40,000$ & 6 & 5.8 \\
$40,001-50,000$ & 7 & 6.7 \\
$50,001-60,000$ & 5 & 4.8 \\
$60,001-70,000$ & 3 & 2.9 \\
$70,001-80,000$ & 2 & 1.9 \\
$80,001-90,000$ & 1 & 1.0 \\
$90,001-100,000$ & 1 & 1.0 \\
$>100,000$ & 1 & 1.0 \\
Total & 104 & 100.0 \\
\hline
\end{tabular}


TABLE 4. Integrated Library System

\begin{tabular}{lcc}
\hline Responses & Response Count & Response Percent \\
\hline Innovative Millennium & 34 & 32.7 \\
Ex Libris Voyager & 22 & 21.2 \\
Ex Libris Aleph & 15 & 14.4 \\
SirsiDynix Unicorn & 13 & 12.5 \\
SirsiDynix Horizon & 8 & 7.7 \\
Talis Alto & 5 & 4.8 \\
Alexandrie & 1 & 1.0 \\
Amicus & 1 & 1.0 \\
GEAC & 1 & 1.0 \\
Inmagic Content Server & 1 & 1.0 \\
OLIB & 1 & 1.0 \\
Polaris ILS & 1 & 1.0 \\
VTLS Virtua & 1 & 1.0 \\
Evergreen & 0 & 0.0 \\
Koha & 0 & 0.0 \\
SirsiDynix Symphony & 0 & 0.0 \\
Total & 104 & 100.0 \\
\hline
\end{tabular}

TABLE 5. How the Library Represents Electronic Serials Titles and Holdings to Patrons

\begin{tabular}{lcc}
\hline Responses & Response Count & Response Percent \\
\hline Via the catalog only & 4 & 4.2 \\
Via the catalog and an A-Z & 92 & 95.8 \\
List & 96 & 100.0 \\
Total & & \\
\hline
\end{tabular}


TABLE 6. MARC Record Service Used By Library

\begin{tabular}{lcc}
\hline Responses & Response Count & Response Percent \\
\hline Serials Solutions 360 & 60 & 62.5 \\
MARCit! & 24 & 25.0 \\
EBSCO MARC records & 5 & 5.2 \\
Cassidy Cataloging & 2 & 2.1 \\
TDNet & 2 & 2.1 \\
As provided by aggregators & 1 & 1.0 \\
$\quad$ and vendors & 1 & 1.0 \\
MARCIVE & 1 & 1.0 \\
TalisBase & 0 & 0.0 \\
CASE & 96 & 100.0 \\
Total & & \\
\hline
\end{tabular}

TABLE 7. Coverage Service Used By Library

\begin{tabular}{lcc}
\hline Responses & Response Count & Response Percent \\
\hline Serials Solutions & 40 & 41.7 \\
SFX & 36 & 37.5 \\
My library doesn't use a & 17 & 17.7 \\
$\quad$ coverage service. & 2 & 2.1 \\
TDNet & 1 & 1.0 \\
EBSCO A-to-Z & 0 & 0.0 \\
CASE & 96 & 100.0 \\
Total & & \\
\hline
\end{tabular}

TABLE 8. Single Record Approach, Separate Records Approach, or Combined

\begin{tabular}{lcc}
\hline Responses & Response Count & Response Percent \\
\hline Separate records approach & 61 & 63.5 \\
Single record approach & 22 & 22.9 \\
Combine elements of both & 13 & 13.5 \\
$\quad$ strategies & 96 & 100.0 \\
Total & & \\
\hline
\end{tabular}


TABLE 9. Methods of Combining Cataloging Approaches

\begin{tabular}{lc}
\hline Responses & Response Count \\
\hline $\begin{array}{l}\text { Separate records except for GPO records, which have } \\
\text { formats combined for a single-record approach }\end{array}$ & 2 \\
$\begin{array}{l}\text { Separate records except for titles that require original } \\
\text { cataloging }\end{array}$ & 2 \\
$\begin{array}{l}\text { In the process of converting from single to separate but not } \\
\text { changing old records }\end{array}$ & 1 \\
$\begin{array}{c}\text { Converting to single record approach for new titles and } \\
\text { question/problem titles, but not doing it systematically }\end{array}$ & 1 \\
$\begin{array}{l}\text { Separate records except for JSTOR titles, which have } \\
\text { formats combined for a single-record approach }\end{array}$ & 1 \\
$\begin{array}{c}\text { Microfilm and print holdings represented on one record, } \\
\text { electronic kept separate }\end{array}$ & 1 \\
$\begin{array}{l}\text { Single record approach if the title used to have print, and } \\
\text { print is still published, but library has switched to online only }\end{array}$ & 1 \\
$\begin{array}{l}\text { Single record if batch-loaded records match on ISSN, but } \\
\text { separate if they do not match on ISSN }\end{array}$ & 1 \\
Total & 10 \\
\hline
\end{tabular}

TABLE 10. Did the Library Transition From Single to Separate As a Result of Adopting a MARC Record Service?

\begin{tabular}{lcc}
\hline Responses & Response Count & Response Percent \\
\hline Yes & 31 & 55.4 \\
No & 25 & 44.6 \\
Total & 56 & 100.0 \\
\hline
\end{tabular}

TABLE 11. Has the Use of the Single Record Approach Created Special Problems in Using the MARC Record Service?

\begin{tabular}{lcc}
\hline Responses & Response Count & Response Percent \\
\hline Yes & 7 & 35 \\
No & 13 & 65 \\
Total & 20 & 100 \\
\hline
\end{tabular}


TABLE 12. Summary of Single Record Approach Problems in Using the MARC Record Service

\begin{tabular}{lc}
\hline Responses & $\begin{array}{c}\text { Number of } \\
\text { responses }\end{array}$ \\
\hline $\begin{array}{l}\text { Presence of duplicate records: } \\
\text { - Inexact / missing matchpoints between print \& electronic: } \\
\text { title may not have matching diacritics or punctuation; ISSN } \\
\quad \text { may not match. }\end{array}$ & 5 \\
- One mentioned that the existence of duplicates is caused by a & \\
shared catalog with other libraries. & \\
- One mentioned using scripts to de-dupe. & 1 \\
Older titles use latest entry rather than successive; a challenge for \\
integrating successive records into catalog \\
$\begin{array}{l}\text { Don't want to delete records if not correct to delete: } \\
\text { - Titles that have special usage specifications have to be } \\
\quad \text { monitored from load to load so that crucial information isn't } \\
\quad \text { lost }\end{array}$ \\
- Have to run delete file manually to avoid deleting records \\
$\quad$ that have print holdings on them
\end{tabular}

TABLE 13. Percentage of Brief Records in MARC Record Service Load

\begin{tabular}{lcc}
\hline Percentage Range & Response Count & Response Percent \\
\hline 0 & 19 & 32.8 \\
$1-10$ & 16 & 27.6 \\
$11-20$ & 3 & 5.2 \\
$21-30$ & 7 & 12.1 \\
$31-40$ & 6 & 10.3 \\
$41-50$ & 1 & 1.7 \\
$51-60$ & 0 & 0.0 \\
$61-70$ & 1 & 1.7 \\
$71-80$ & 3 & 5.2 \\
$81-90$ & 1 & 1.7 \\
$90-100$ & 1 & 1.7 \\
Total & 58 & 100.0 \\
\hline
\end{tabular}


TABLE 14. Common Features of MARC Record Service Brief Records

\begin{tabular}{lcc}
\hline Responses & $\begin{array}{c}\text { Response } \\
\text { Count }\end{array}$ & $\begin{array}{c}\text { Response } \\
\text { Percent }\end{array}$ \\
\hline Lack of 780/785 linking fields & 30 & 51.7 \\
No persistent unique bibliographic record identifier & 18 & 31.0 \\
Incorrect ISSN & 15 & 25.9 \\
Incorrect use of diacritics & 15 & 25.9 \\
Duplicate records in the same batch & 11 & 19.0 \\
Inconsistent use of acronyms & 10 & 17.2 \\
Lack of detail in the records & 9 & 15.5 \\
We do not use brief records & 7 & 12.1 \\
General material designation displays incorrectly & 6 & 10.3 \\
Don't know & 3 & 5.2 \\
Incorrect title proper, including placement of initial & & 5.2 \\
$\quad$ articles at end of title and typos & 3 & 1.7 \\
We haven't noticed problems & 1 & 1.7 \\
"Random inaccuracies" & 1 & 1.7 \\
No Chinese records available / incorrect Chinese & & 1.7 \\
$\quad$ records (transliterations incorrect) & 1 & 1.7 \\
Character encoding is not MARC8 compliant & 1 & 1.7 \\
Do not always overlay properly & 1 & \\
Loads supply records for non-serials as well as & & \\
$\quad$ serials & 1 & \\
Total & 131 & \\
\hline
\end{tabular}

Note: 58 respondents provided 131 answers. Percentages were calculated using 58 as the total. 
TABLE 15. Common Features of MARC Record Service Full Records

\begin{tabular}{|c|c|c|}
\hline Responses & $\begin{array}{c}\text { Response } \\
\text { Count }\end{array}$ & $\begin{array}{c}\text { Response } \\
\text { Percent }\end{array}$ \\
\hline $\begin{array}{l}\text { Records contain notes for print or microform } \\
\text { versions }\end{array}$ & 24 & 48 \\
\hline Fixed fields have incorrect values for online version & 12 & 24 \\
\hline $\begin{array}{l}\text { ISSN for electronic format is in } 776 \text { field rather } \\
\text { than } 022 \text { field }\end{array}$ & 9 & 18 \\
\hline $\begin{array}{l}\text { I don't know / I haven't noticed serious or common } \\
\text { problems }\end{array}$ & 9 & 18 \\
\hline Records are missing 245 |h [electronic resource] & 6 & 12 \\
\hline Links in 856 fields are incorrect & 6 & 12 \\
\hline $\begin{array}{l}\text { Coverage dates in } 008 \text { are incorrect for records with } \\
785 \text { fields }\end{array}$ & 4 & 8 \\
\hline \multicolumn{3}{|l|}{ Records are fine the way they are, because we } \\
\hline $\begin{array}{l}\text { know how we want to modify the records, or we } \\
\text { ask the vendor to modify the records }\end{array}$ & 3 & 6 \\
\hline Title changes are not documented correctly & 2 & 4 \\
\hline Sometimes we receive French language records & 1 & 2 \\
\hline Incorrect spelling & 1 & 2 \\
\hline CD-ROM records provided if print not available & 1 & 2 \\
\hline Chinese / Japanese / Korean script loads incorrectly & 1 & 2 \\
\hline There are too many subject headings & 1 & 2 \\
\hline There are no MeSH headings & 1 & 2 \\
\hline There are words in the 050 rather than call numbers & 1 & 2 \\
\hline Total & 82 & \\
\hline
\end{tabular}

Note: 50 respondents provided 82 answers. Percentages were calculated using 50 as the total. 
TABLE 16. Modifications Made to Records After Batch Loads

\begin{tabular}{lcc}
\hline Responses & $\begin{array}{c}\text { Response } \\
\text { Count }\end{array}$ & $\begin{array}{c}\text { Response } \\
\text { Percent }\end{array}$ \\
\hline We make no modifications & 28 & 39.4 \\
We batch-update records using the integrated & 25 & 35.2 \\
$\quad$ library system & 15 & 21.1 \\
We fix records individually by hand & 13 & 18.3 \\
We batch-update records using scripts & 8 & 11.3 \\
$\begin{array}{l}\text { We modify records before loading. (Four report } \\
\quad \text { using MarcEdit) }\end{array}$ & 4 & 5.6 \\
$\quad \begin{array}{l}\text { We notify the MARC record service vendor to fix } \\
\text { the problems }\end{array}$ & 1 & 5.6 \\
$\begin{array}{l}\text { We delete "online resources" from 655 } \\
\text { We set up a material type code in the integrated } \\
\quad \text { library system for batch-loaded bibs so the } \\
\quad \begin{array}{l}\text { appropriate icon displays for these items } \\
\text { Total }\end{array}\end{array}$ & 1 & 5.6 \\
\hline
\end{tabular}

Note: 71 respondents provided 95 answers. Percentages were calculated using 71 as the total.

Table 17. Suggested Enhancements/Improvements to MARC Records

\begin{tabular}{lcc}
\hline Responses & $\begin{array}{c}\text { Response } \\
\text { Count }\end{array}$ & $\begin{array}{c}\text { Response } \\
\text { Percent }\end{array}$ \\
\hline We want fewer brief records & 8 & 22.9 \\
We are satisfied with the records & 7 & 20.0 \\
Improve accuracy of records & 6 & 17.1 \\
Add persistent ID to brief records & 5 & 14.3 \\
Fix problems with subject headings in full records: fewer & 3 & 8.6 \\
$\quad$ Library of Congress headings, provide English-only & & 8.6 \\
$\quad$ headings & 3 & 5.7 \\
Want to use OCLC records if no CONSER available & & 5.7 \\
CONSER related problems: if CONSER print or microform & 2 & 5.7 \\
$\quad$ records are used, the fixed fields should be corrected; & & 2.9 \\
$\quad$ supposed to be CONSER records but not & 2 & 2.9 \\
Don't know yet / no comment & 2 & 2.9 \\
Provide more detailed brief records & 1 & 2.9 \\
Update brief records more quickly & 1 & 2.9 \\
Leave OCLC number in records & 1 & \\
Add ranking to choice of record types from vendor & 1 & \\
$\quad$ fields & & \\
Base all records on online format \\
Total
\end{tabular}


Note: 35 respondents provided 43 answers. Percentages were calculated using 35 as the total.

TABLE 18. Best Liked Features of MARC Record Service

\begin{tabular}{lcc}
\hline Responses & $\begin{array}{c}\text { Response } \\
\text { Count }\end{array}$ & $\begin{array}{c}\text { Response } \\
\text { Percent }\end{array}$ \\
\hline $\begin{array}{l}\text { Satisfaction of being able to spend time on projects } \\
\text { other than cataloging aggregated titles }\end{array}$ & 53 & 74.6 \\
$\begin{array}{l}\text { Satisfaction of knowing that all titles have } \\
\text { bibliographic records }\end{array}$ & 51 & 71.8 \\
Ease of use in loading records & 49 & 69.0 \\
$\begin{array}{l}\text { Accuracy of bibliographic records } \\
\text { Services create access to titles that would otherwise not } \\
\text { have access }\end{array}$ & 14 & 19.7 \\
I don't know & 7 & 9.9 \\
Total & 1 & 1.4 \\
\hline
\end{tabular}

Note: 71 respondents provided 175 answers. Percentages were calculated using 71 as the total.

\section{TABLE 19. Least Liked Features of MARC Record Service}

\begin{tabular}{lcc}
\hline Responses & $\begin{array}{c}\text { Response } \\
\text { Count }\end{array}$ & $\begin{array}{c}\text { Response } \\
\text { Percent }\end{array}$ \\
\hline Inaccuracy of bibliographic records & 25 & 43.1 \\
Time spent cleaning up bibliographic records after the & 18 & 31.0 \\
$\quad$ load / clean up is too extensive & 12 & 20.7 \\
Difficulty of the load process & 6 & 10.3 \\
We are satisfied with the service as it is & 4 & 6.9 \\
Too many brief records or presence of duplicate briefs & 3 & 5.2 \\
Problems with loading the records & 3 & 5.2 \\
Don't know / don't have time to check the records & 2 & 3.4 \\
We don't receive records for all titles in the & 73 & \\
$\quad$ knowledgebase & & \\
Total & &
\end{tabular}

Note: 58 respondents provided 73 answers. Percentages were calculated using 58 as the total. 
TABLE 20. Suggested Enhancements/Improvements to the Overall Load Process

\begin{tabular}{lcc}
\hline Responses & $\begin{array}{c}\text { Response } \\
\text { Count }\end{array}$ & $\begin{array}{c}\text { Response } \\
\text { Percent }\end{array}$ \\
\hline The service works well enough & 7 & 23.3 \\
I don't know / no comment & 4 & 13.3 \\
Provide better brief records & 3 & 10.0 \\
Make it easier or more automated & 3 & 10.0 \\
ILS has trouble handling load & 2 & 6.7 \\
We would like to receive "cleaner" records & 2 & 6.7 \\
It's not possible to improve the process & 2 & 6.7 \\
Records are difficult to overlay & 1 & 3.3 \\
Provide more full records & 1 & 3.3 \\
Provide better authority control for records & 1 & 3.3 \\
Provide more specific change reports: we want to & & \\
$\quad$ know which fields have been changed in which & 1 & 3.3 \\
$\quad$ records & 1 & 3.3 \\
We would like to spend less staff time on it & 1 & 3.3 \\
We would like better ILS customer service & 1 & 3.3 \\
We want to use ISSN-L & 1 & 3.3 \\
Running scripts makes it impossible to load & & 3.3 \\
everything at once & 1 & 3.3 \\
Provide more frequent updates & 1 & \\
$\quad$ CONould like to use OCLC records when & 33 & \\
Total & &
\end{tabular}

Note: 30 respondents provided 33 answers. Percentages were calculated using 30 as the total. 
TABLE 21. Further Comments on the MARC Record Service

\begin{tabular}{|c|c|c|}
\hline Responses & $\begin{array}{c}\text { Response } \\
\text { Count }\end{array}$ & $\begin{array}{c}\text { Response } \\
\text { Percent }\end{array}$ \\
\hline We like the additional access provided by the service & 6 & 23.1 \\
\hline We are satisfied with the service & 4 & 15.4 \\
\hline $\begin{array}{l}\text { Despite problems, it is a necessary service for the } \\
\text { library }\end{array}$ & 2 & 7.7 \\
\hline Single record approach is difficult to achieve using a & & \\
\hline $\begin{array}{l}\text { MARC record service; would like easier } \\
\text { implementation for single record approach }\end{array}$ & 2 & 7.7 \\
\hline ARL title reporting will be problematic & 1 & 3.8 \\
\hline We would like real-time updates & 1 & 3.8 \\
\hline Allows library staff to do other projects & 1 & 3.8 \\
\hline $\begin{array}{l}\text { Would like to see e-book MARC records in with } \\
\text { serials records }\end{array}$ & 1 & 3.8 \\
\hline $\begin{array}{l}\text { Implementation affected institution's organization: } \\
\text { serials cataloging moved to Acquisitions } \\
\text { department }\end{array}$ & 1 & 3.8 \\
\hline We would like fewer duplicate records & 1 & 3.8 \\
\hline Most problems are coverage problems & 1 & 3.8 \\
\hline $\begin{array}{l}\text { We are trying to use both the SFX knowledgebase } \\
\text { and Serials Solutions MARC records, which has } \\
\text { created problems }\end{array}$ & 1 & 3.8 \\
\hline $\begin{array}{l}\text { I don't want to have to examine the bibs closely to } \\
\text { make sure of their accuracy }\end{array}$ & 1 & 3.8 \\
\hline I wish it were more staff user-friendly & 1 & 3.8 \\
\hline Vendors should improve record quality & 1 & 3.8 \\
\hline We are unable to overlay certain records & 1 & 3.8 \\
\hline $\begin{array}{l}\text { Staff thought would be receiving online-only records } \\
\text { (mismatch between expectations of what would be } \\
\text { provided and what was actually provided) }\end{array}$ & 1 & 3.8 \\
\hline Total & 26 & 100.0 \\
\hline
\end{tabular}




\section{Appendix: Survey Instrument}

1. Please indicate by selecting the "yes" below that you give consent for me to use your survey responses in my research, according to the description above.

If you do not wish to participate in the survey, you may exit from the survey now.

\section{Demographic information}

The next four questions are intended to provide a bit of background about your library environment.

2. What is your library setting?
○ Academic
○ Public
- Special
○ Other (please specify)

3. Where is your library located?
$\circ$ United States
- United Kingdom
O Other (please specify)

4. Approximately how many electronic serials titles does your library have access to?

5. Which Integrated Library System does your library use?
$\circ$ Evergreen
- Ex Libris Aleph
- Ex Libris Voyager
- Innovative Millennium
○ Koha
- Polaris ILS
- SirsiDynix Unicorn
- SirsiDynix Symphony
- Talis Alto
- VTLS Virtua
- Other (please specify)

\section{Questions about the MARC Record Service}

The next questions ask about your experiences with a MARC record service.

6. How does your library represent your electronic serials titles and holdings to your patrons?

○ Via the catalog only

- Via the catalog and an A-to-Z list outside of the catalog

7. Which MARC Record Service does your library use?

○ CASE 
- EBSCO MARC records

- MARCit!

- Serials Solutions 360 MARC Updates

○ Other (please specify)

8. Do you also use a coverage service such as Serials Solutions 360 Link (including

Serials Solutions knowledgebase), SFX, or CASE? If so, which service?

○ My library doesn't use a coverage service.

- CASE

○ SFX

- Serials Solutions 360 Link

○ Other (please specify)

9. For your serials titles, do you use the single record approach, separate records approach, or combine elements of both strategies?

- Single record approach

- Separate records approach

- Combine elements of both strategies

If your library combines elements of both, would you please explain this?

10. Did your library transition from using a single record approach to a separate record approach as a result of implementing the MARC record service?

○ Yes

○ No

11. Has the use of the single record approach created special problems for you in using the MARC record service?
○ No
$\circ$ Yes

If yes, would you please indicate what problems have arisen?

\section{MARC Record Service bibliographic records}

The next questions ask about the bibliographic records that are loaded into the catalog.

12. In a typical load, what percentage of the bibliographic records loaded would you estimate are brief bibliographic records?

13. Which of the following are common in the MARC Record Service's brief records? (Please select all that apply.)

- No persistent unique bibliographic record identifier

- Duplicate records in the same batch

- Incorrect ISSN

O Inconsistent use of acronyms

- Incorrect use of diacritics 
○ Lack of 780/785 linking fields

- General material designation displays incorrectly

- Other (please specify)

14. Which of the following are common in the MARC Record Service's full bibliographic records? (Please select all that apply.)

- Fixed fields have incorrect values for online version

- Records are missing 245 |h [electronic resource]

- ISSN for electronic format is in 776 field rather than 022 field

- Records contain notes for print or microform versions

- Coverage dates in 008 are incorrect for records with 785 fields

$\circ$ Links in 856 fields are incorrect

- Other (please specify)

15. After your library loads the bibliographic records, how do you modify them? (Please select all that apply.)

- We make no modifications

○ We batch-update records using the integrated library system

- We batch-update records using scripts

- We fix records individually by hand

- Other (please specify)

16. How would you enhance/improve the MARC records, either full or brief, if you could?

\section{MARC Record Service features}

17. What do you like best about the MARC record service? (Please select all that apply.)

- Ease of use in loading records

- Accuracy of bibliographic records

- Satisfaction of knowing that all titles have bibliographic records

- Satisfaction of being able to spend time on projects other than cataloging aggregated titles

O Other (please specify)

18. What do you like least about the MARC record service?

○ Difficulty of the load process

- Inaccuracy of bibliographic records

- Time spent cleaning up bibliographic records after the load

$\circ$ Other (please specify)

19. How would you enhance/improve the overall load process, if you could?

20. Do you have any further comments about the MARC Record Service? 
21. Are you willing to provide your e-mail address so that I may contact you for further information regarding the survey? If so, please enter your e-mail address here. 


\section{Appendix II: Corrigenda}

1.) Page 7

"Choices include CONSER online records, CONSER print, microform, or CD-ROM records, and CONSER 'neutral' records (print records that do not explicitly indicate that they describe the print format)."

2.) Page 21

"Twenty-six participants provided 27 responses to the final question, "Do you have any further comments about the MARC Record Service?"

3.) Page 25

TABLE 2. Library Location

\begin{tabular}{lcc}
\hline Responses & Response Count & Response Percent \\
\hline United States & 79 & 76.0 \\
United Kingdom & 9 & 8.7 \\
Australia & 6 & 5.8 \\
Canada & 4 & 3.8 \\
Lebanon & 2 & 1.9 \\
Finland & 1 & 1.0 \\
New Zealand & 1 & 1.0 \\
North Africa & 1 & 1.0 \\
Pakistan & 1 & 1.0 \\
Total & 104 & $100.2^{*}$ \\
\hline
\end{tabular}

*Due to rounding.

4.) Page 25

TABLE 3. Approximate Number of Electronic Serials

\begin{tabular}{lcc}
\hline Responses & Response Count & Response Percent \\
\hline Unknown & 6 & 5.8 \\
$0-1000$ & 4 & 3.8 \\
$1001-10,000$ & 16 & 15.4 \\
$10,001-15,000$ & 13 & 12.5 \\
$15,001-20,000$ & 10 & 9.6 \\
$20,001-25,000$ & 8 & 7.7 \\
$25,001-30,000$ & 13 & 12.5 \\
$30,001-35,000$ & 8 & 7.7 \\
$35,001-40,000$ & 6 & 5.8 \\
$40,001-50,000$ & 7 & 6.7 \\
$50,001-60,000$ & 5 & 4.8 \\
$60,001-70,000$ & 3 & 2.9 \\
$70,001-80,000$ & 2 & 1.9 \\
$80,001-90,000$ & 1 & 1.0 \\
$90,001-100,000$ & 1 & 1.0 \\
$>100,000$ & 1 & 1.0 \\
Total & 104 & $100.1 *$ \\
\hline
\end{tabular}

*Due to rounding 
5.) Page 26

TABLE 4. Integrated Library System

\begin{tabular}{lcc}
\hline Responses & Response Count & Response Percent \\
\hline Innovative Millennium & 34 & 32.7 \\
Ex Libris Voyager & 22 & 21.2 \\
Ex Libris Aleph & 15 & 14.4 \\
SirsiDynix Unicorn & 13 & 12.5 \\
SirsiDynix Horizon & 8 & 7.7 \\
Talis Alto & 5 & 4.8 \\
Alexandrie & 1 & 1.0 \\
Amicus & 1 & 1.0 \\
GEAC & 1 & 1.0 \\
Inmagic Content Server & 1 & 1.0 \\
OLIB & 1 & 1.0 \\
Polaris ILS & 1 & 1.0 \\
VTLS Virtua & 1 & 1.0 \\
Evergreen & 0 & 0.0 \\
Koha & 0 & 0.0 \\
SirsiDynix Symphony & 0 & 0.0 \\
Total & 104 & $100.3^{*}$ \\
\hline
\end{tabular}

*Due to rounding

6.) Page 27

TABLE 6. MARC Record Service Used By Library

\begin{tabular}{lcc}
\hline Responses & Response Count & Response Percent \\
\hline Serials Solutions 360 & 60 & 62.5 \\
MARCit! & 24 & 25.0 \\
EBSCO MARC records & 5 & 5.2 \\
Cassidy Cataloging & 2 & 2.1 \\
TDNet & 2 & 2.1 \\
As provided by aggregators & 1 & 1.0 \\
$\quad$ and vendors & 1 & 1.0 \\
MARCIVE & 1 & 1.0 \\
TalisBase & 0 & 0.0 \\
CASE & 96 & $99.9^{*}$ \\
Total & & \\
\hline
\end{tabular}

*Due to rounding 
6.) Page 27

TABLE 8. Single Record Approach, Separate Records Approach, or Combined

\begin{tabular}{lcc}
\hline Responses & Response Count & Response Percent \\
\hline Separate records approach & 61 & 63.5 \\
Single record approach & 22 & 22.9 \\
Combine elements of both & 13 & 13.5 \\
$\quad$ strategies & 96 & $99.9 *$ \\
\hline
\end{tabular}

*Due to rounding

7.) Page 35

TABLE 21. Further Comments on the MARC Record Service

\begin{tabular}{|c|c|c|}
\hline Responses & $\begin{array}{l}\text { Response } \\
\text { Count }\end{array}$ & $\begin{array}{l}\text { Response } \\
\text { Percent }\end{array}$ \\
\hline We like the additional access provided by the service & 6 & 23.1 \\
\hline We are satisfied with the service & 4 & 15.4 \\
\hline $\begin{array}{l}\text { Despite problems, it is a necessary service for the } \\
\text { library }\end{array}$ & 2 & 7.7 \\
\hline Single record approach is difficult to achieve using a & & \\
\hline $\begin{array}{l}\text { MARC record service; would like easier } \\
\text { implementation for single record approach }\end{array}$ & 2 & 7.7 \\
\hline ARL title reporting will be problematic & 1 & 3.8 \\
\hline We would like real-time updates & 1 & 3.8 \\
\hline Allows library staff to do other projects & 1 & 3.8 \\
\hline $\begin{array}{l}\text { Would like to see e-book MARC records in with } \\
\text { serials records }\end{array}$ & 1 & 3.8 \\
\hline $\begin{array}{l}\text { Implementation affected institution's organization: } \\
\text { serials cataloging moved to Acquisitions } \\
\text { department }\end{array}$ & 1 & 3.8 \\
\hline We would like fewer duplicate records & 1 & 3.8 \\
\hline Most problems are coverage problems & 1 & 3.8 \\
\hline $\begin{array}{l}\text { We are trying to use both the SFX knowledgebase } \\
\text { and Serials Solutions MARC records, which has } \\
\text { created problems }\end{array}$ & 1 & 3.8 \\
\hline $\begin{array}{l}\text { I don't want to have to examine the bibs closely to } \\
\text { make sure of their accuracy }\end{array}$ & 1 & 3.8 \\
\hline I wish it were more staff user-friendly & 1 & 3.8 \\
\hline Vendors should improve record quality & 1 & 3.8 \\
\hline We are unable to overlay certain records & 1 & 3.8 \\
\hline $\begin{array}{l}\text { Staff thought would be receiving online-only records } \\
\text { (mismatch between expectations of what would be } \\
\text { provided and what was actually provided) }\end{array}$ & 1 & 3.8 \\
\hline Total & 27 & \\
\hline
\end{tabular}

Note: 26 respondents provided 27 answers. Percentages were calculated using 26 as the total. 